\title{
Students' worksheets on work and energy using kokami media: An effort to increase the student's cognitive achievement
}

\author{
Mastuang $^{1 *}$, Alfis Sa'adah ${ }^{2}$, Sri Hartini ${ }^{3}$, Mustika Wati ${ }^{4}$, Saiyidah Mahtari ${ }^{5}$, Misbah $^{6}$, and \\ Nurul F. Sulaeman ${ }^{7,8}$

\footnotetext{
1, 2, 3, 4, 5, 6 Physics Education Study Program, Universitas Lambung Mangkurat, Banjarmasin, Indonesia

${ }^{7}$ Department of Physics Education, Faculty of Teacher Training and Education, Universitas Mulawarman, Indonesia

${ }^{8}$ Department of Science Education, Graduate School of Science and Technology, Shizuoka University, Japan
}

*Corresponding Address: mastuang_pfis@ulm.ac.id

\begin{tabular}{|c|c|}
\hline Article Info & ABSTRACT \\
\hline Article history: & \multirow{5}{*}{$\begin{array}{l}\text { This study aims to describe the feasibility of student worksheets on natural } \\
\text { science with Kokami (Kotak Kartu misterius/ mysterious card box) media to } \\
\text { increase the students' learning outcome. The themes of the developed } \\
\text { product are work and energy for junior high school level students. The } \\
\text { specific objectives of this study were to describe the validity, practicality, } \\
\text { and effectiveness of natural science students' worksheets with Kokami } \\
\text { media. The type of this research is research and development with the } \\
\text { ADDIE development model. The test subjects were } 36 \text { students from one of } \\
\text { the public junior high school in Barito Kuala regency. The instruments of } \\
\text { this research were validation sheets, questionnaires, and learning outcomes } \\
\text { tests. The results showed that: 1) the validity of students' worksheets of } \\
\text { natural science with the Kokami media was included in the highly valid } \\
\text { category, (2) the practicality of students' worksheets of natural science with } \\
\text { the Kokami media was in the very good category, and (3) the effectiveness } \\
\text { of students' worksheets of natural science with Kokami media was in the } \\
\text { high category. It can be concluded that the natural science students' } \\
\text { worksheets with Kokami media were feasible to be used at the junior high } \\
\text { school level. Kokami media can be an effective and attractive alternative } \\
\text { learning media in learning physics. }\end{array}$} \\
\hline $\begin{array}{l}\text { Received: September } 18^{\text {th }}, 2019 \\
\text { Accepted: March } 2^{\text {nd }}, 2020 \\
\text { Published. Anril } 29^{\text {th }}\end{array}$ & \\
\hline & \\
\hline Keywords: & \\
\hline $\begin{array}{l}\text { Kokami media; } \\
\text { Natural science; } \\
\text { Student worksheet }\end{array}$ & \\
\hline
\end{tabular}

(C) 2020 Physics Education Department, UIN Raden Intan Lampung, Indonesia.

\section{INTRODUCTION}

Qualified education is supported by an effective learning system (Hartini et al., 2018). The learning process that involves students' activity, education, motivation, and encouragement can be manifested by the skills of the teacher. Learning media is aids that facilitate the delivery of information from the teacher to students with interesting stimuli, so students will be easy to process the information received (Hartini et al., 2017; Labibah et al., 2019; Wati et al., 2018). Media that can be used in the teaching and learning process are varied such as modules (Hartini et al., 2018;
Mastuang et al., 2019), instructional medium (Wati et al., 2018), multimedia (Zainuddin et al., 2019) and worksheets (Ardan, 2016; Utami, 2016). A sheet containing summaries, material, and instructions referenced from basic competencies that must be achieved in carrying out learning tasks is an understanding of students' worksheets (Prastowo, 2014). Students' worksheets made must be interesting because increased interest can lead to students' cognitive improvement (Barniol \& Zavala, 2016; Zulyadaini, 2017) and so that learning activities do not quickly make students 
saturated in learning (Ekantini \& Wilujeng, 2018; Nasution \& Sinaga, 2017).

One method that can be used to reduce students' boredom in learning is game. Game is an activity carried out to get pleasure that can shape the personality and development of students such as morals, social, and emotional (Hwang et al., 2015). In such a way, students do not feel that they are learning and do not feel bored especially with lessons full of concepts and formulas, for example, physics. However, the development of worksheets that could combine both the needs of learning and interesting game is rare to found.

Physics is one part of natural science which is an important subject in the world of education (Daineko et al., 2017). Natural science learning aims to develop students' ability to think (Forawi, 2016; Sriarunrasmee et al., 2015). Also, the teacher must provide understanding to students about the natural science products produced (Berland et al., 2016).

Based on the results of interviews with science teachers at one of public junior high school in Barito Kuala Regency, the students' handbook was only a textbook from the publisher and did not use students' worksheets. The absence of this worksheet is due to limited knowledge and teacher time to develop student worksheets. This is in line with the results of the study (Huizinga et al., 2014) that teachers have three gaps in expertise design with three domains 1) expertise curriculum design, 2) pedagogical content knowledge, and 3) expertise consistency. Based on the results of the analysis, the textbook contains material, multiple-choice questions, examples of questions, and essays. Besides, in the learning process, there are no game activities performed.

Worksheets have an important role as a means to help and facilitate students in interacting with the material provided. The initial ability of students is low, so students need guidance from the teacher through the worksheet. Game techniques can increase enjoyment levels of students and this increase in enjoyment correlated positively with higher-order thinking (Anesia et al., 2018; Crocco et al., 2016). Based on the theory of developmental psychology, at the age of the junior high school, children are more likely to play (Haerani, 2016).

One way that can be done to create interactive and fun learning for students is to provide teaching materials in the form of student worksheets in which educational games are inserted. The game that is raised here is Kokami which is a combination of games and media, which can invite students' attention in learning (Nuraeni et al., 2015). Kokami media serves to stimulate interest, attention and instill knowledge to students with interest (Juneau, 2017). Kokami media can be used by the teacher when giving questions, explaining the material, and as presentation assignments to students (Rahmawati, 2017). Learning through Kokami media allows students to learn while playing about the material being taught so that the lessons given are more memorable (Widodo, 2017). This is in line with the results of research that the use of Kokami as a learning medium can increase activity (Putri et al., 2017), creative thinking skills (Istiqomah et al., 2016), critical thinking (Marga et al., 2018), and learning outcomes (Rachmawati, 2019).

In this study, students' worksheets were developed using Kokami media on work and energy materials at the junior high school level. The Kokami media developed consists of word square, guess the picture, guess the numbers, crossword puzzle, and guess the word. The aim of the research, in general, is to describe the feasibility of natural science student worksheets with Kokami media to increase student's learning outcomes. The specific objectives of this study were to describe: 1) the validity students' worksheets of natural science with Kokami media, 2) the practicality of students' worksheets of natural science with Kokami media, and 3) the effectiveness of students' 
worksheets of natural science with Kokami media.

\section{METHODS}

The type of research used was research and development with ADDIE as the development model (Analyze, Design, Develop, Implement, and Evaluate). The steps of ADDIE development can be seen in Table 1. The trial subjects were 36 students from one public junior high school in Barito Kuala regency.

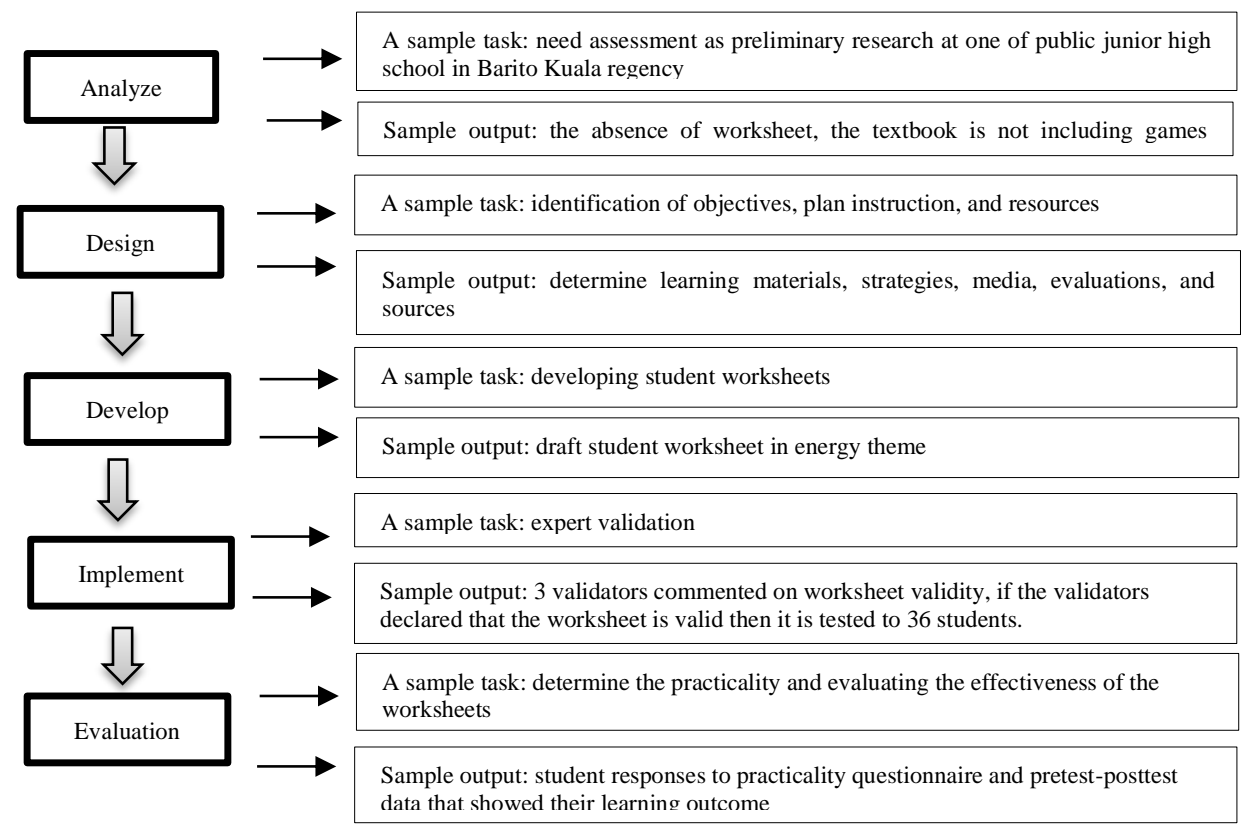

Figure 1. Steps of ADDIE Development Model

The research instruments used were in the form of student worksheets, response questionnaire sheets, and student learning outcomes. Data analysis was carried out by analyzing the validity, practicality, and effectiveness of the student worksheets. The validation of students' worksheets was carried out by three validators. The validity categories are determined by the percentage of validation results, then adjusted to the validation criteria (Hartini et al., 2017). The category validity of the student worksheet can be seen in Table 1 .

Table 1. Category validity of student worksheet

\begin{tabular}{ccc}
\hline No & Interval & Category \\
\hline 1 & $3,25 \leq \mathrm{x} \leq 4,00$ & Excellent \\
2 & $2,50 \leq \mathrm{x}<3,25$ & Good \\
3 & $1,75 \leq \mathrm{x}<2,50$ & Moderate \\
4 & $1,00 \leq \mathrm{x}<1,75$ & Low \\
\hline
\end{tabular}

The practicality of student worksheets can be seen from the questionnaire given to students after the learning had been completed which covers the aspects of the ease of use, the benefits, and the efficiency. The average value of student response results was categorized according to the practicality criteria (Widoyoko, 2014). The response questionnaire used had been validated by the experts and had a validity value of 3.12 with a valid category and a very high reliability of 0.94 . Student questionnaire validation included aspects of instrument format, instrument content, and construction and language. The practicality category of student worksheets can be seen in Table 2.

Table 2. Practicality Category of Student Worksheet

\begin{tabular}{ccc}
\hline No & Interval & Category \\
\hline 1 & $3,25 \leq \mathrm{x} \leq 4,00$ & Excellent \\
2 & $2,50 \leq \mathrm{x}<3,25$ & Good \\
3 & $1,75 \leq \mathrm{x}<2,50$ & Moderate \\
4 & $1,00 \leq \mathrm{x}<1,75$ & Low \\
\hline
\end{tabular}


The effectiveness of students' worksheets was measured from student learning outcomes tests. The validation of the learning outcomes test in terms of construction aspects and the validity of the items are categorized very valid with very high reliability amounted to 0.92 . The learning outcomes test consists of 10 essays. Analysis of the effectiveness of students' worksheets is calculated through the normalized gain (N-gain) test (Hake, 1998).

\section{RESULTS AND DISCUSSION}

\section{Analysis}

This research and development were aimed to describe the feasibility of student worksheets with Kokami media for the eighth-grade junior high school students. At this stage, it is important to analyze the needs of the developed product by conducting a preliminary study by interviewing the teacher and analyzing information from the results of the interview. Researchers conducted curriculum analysis to determine products that are in line with core competencies and basic competencies.

\section{Design}

The product developed is a student worksheet. Teachers have not used worksheets in learning activities, even though student worksheets have an important role in learning activities as student companions to practice student independence. So, the researchers chose worksheets as developed teaching material.

The products produced from this research are worksheets of natural science students with Kokami media on work and energy material. The student worksheets developed contain titles, introductory words, instructions for using student worksheets, brief information, objectives, tools/materials needed in the experiment, work steps, tasks to be done, reports to do and the game of Kokami. Kokami media is one of the learning media in the form of a box that contains several mysterious cards (Rahmawati, 2017). Said to be mysterious because students do not know the contents of the card.

This section, it is explained the results of research and at the same time is given a comprehensive discussion. Results can be presented in figures, graphs, tables, and others that make the reader understand easily. The discussion can be made in several sub-sections. The errors that often occur include a subscript on the quantity of vacuum permeability, for example, must be written using zero instead of the letter "o". The use of a foreign prefix "non" is not separated from the next word.

\section{Development}

The third stage is the interpretation of planning. At this stage, the product draft has been produced. The student worksheets developed to consist of three meetings are work, observing changes in the form of energy, and knowing the conservation laws of energy. The media developed consists of word square, guess the picture, guess the numbers, crossword puzzle, and guess the word. A description of the draft worksheet that is developed can be seen in Table 3 . 
Table 3. Description of the Draft of the Product

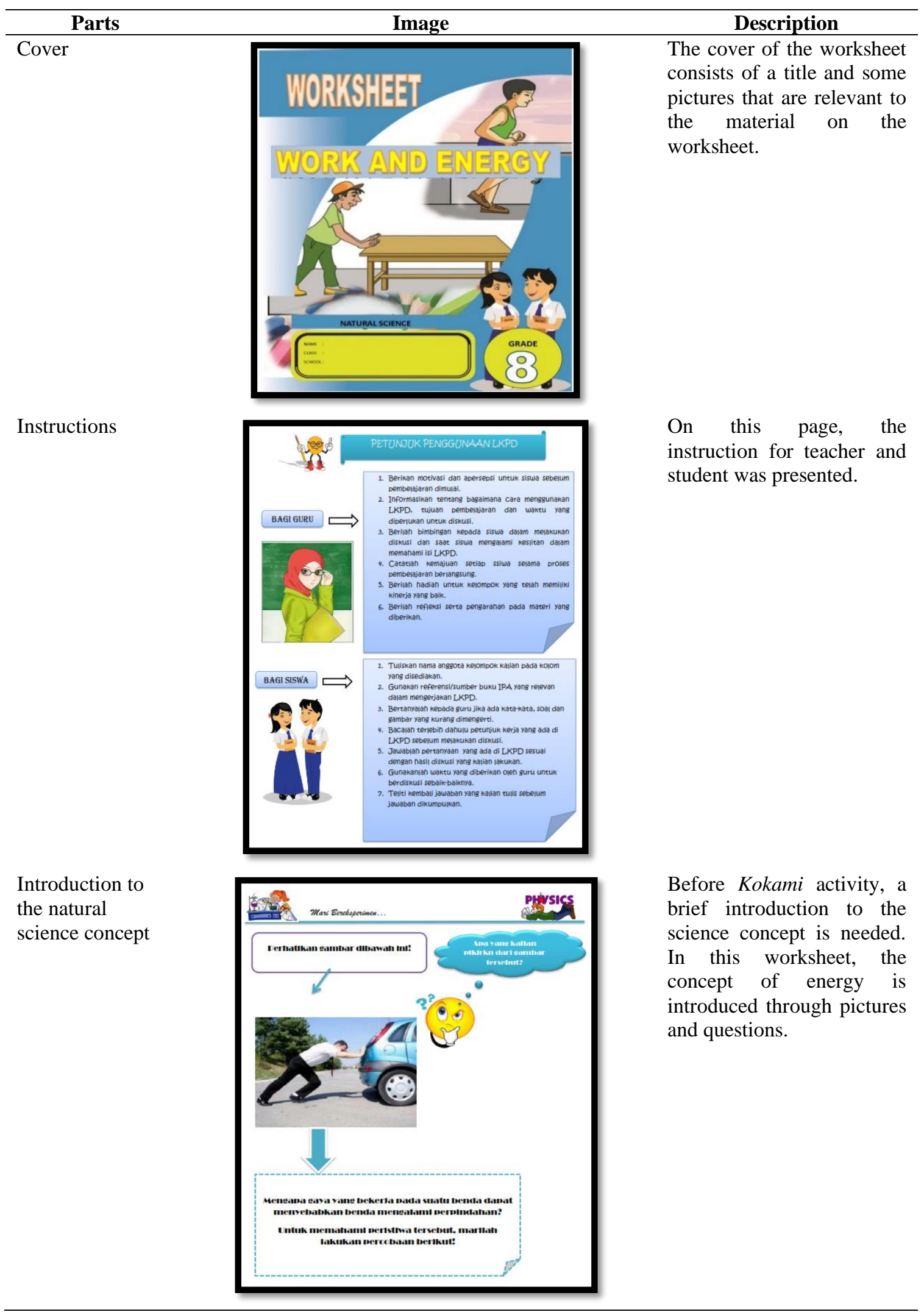




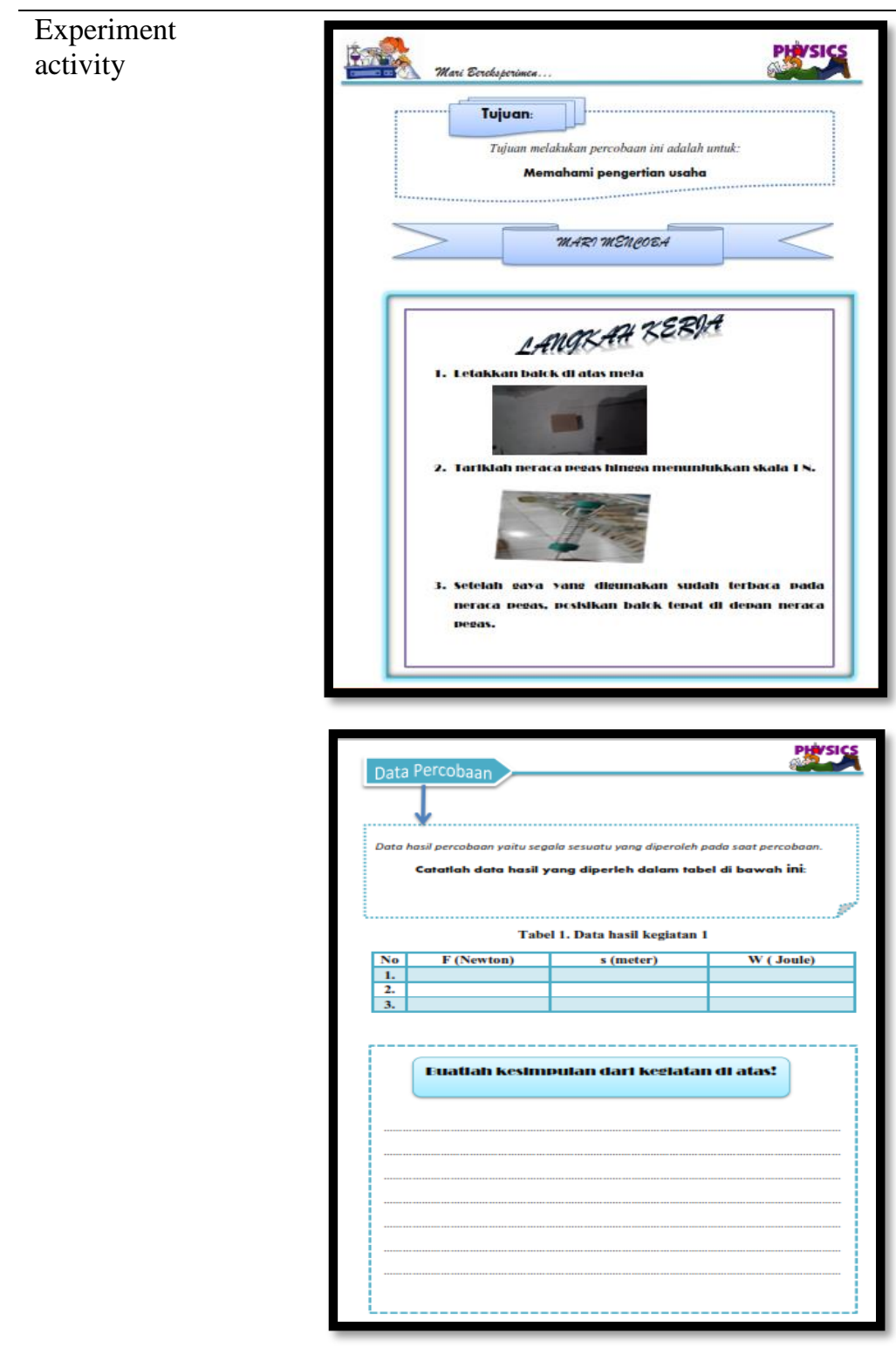

Activity on the worksheet

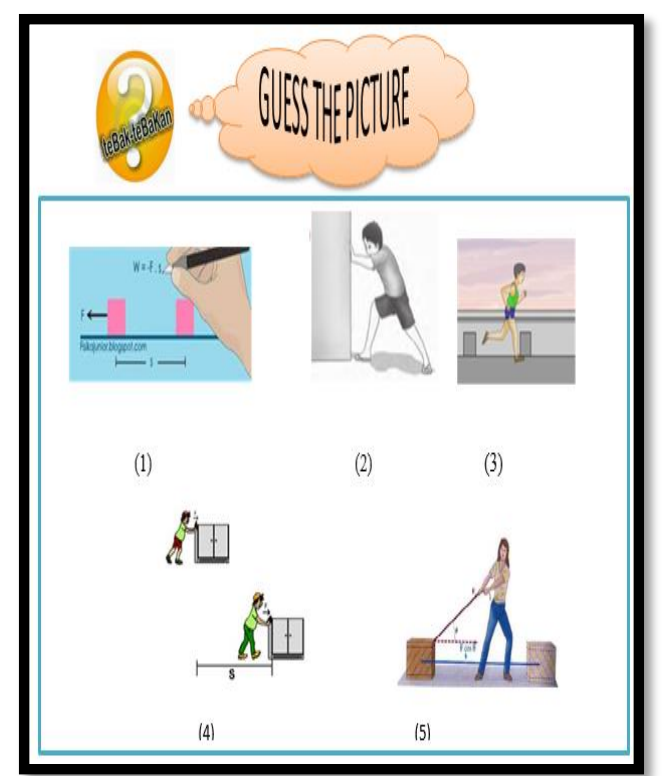

The brief experiment activity and data collection about a work topic

On the worksheet, there are answer choices with questions found in the Kokami media. Students group representatives take one question card from the Kokami media randomly. Students in groups are responsible for completing questions on the card and writing answers on a worksheet. Moreover, the word square also designed to recall students understanding about some concepts that related to Work topic. 

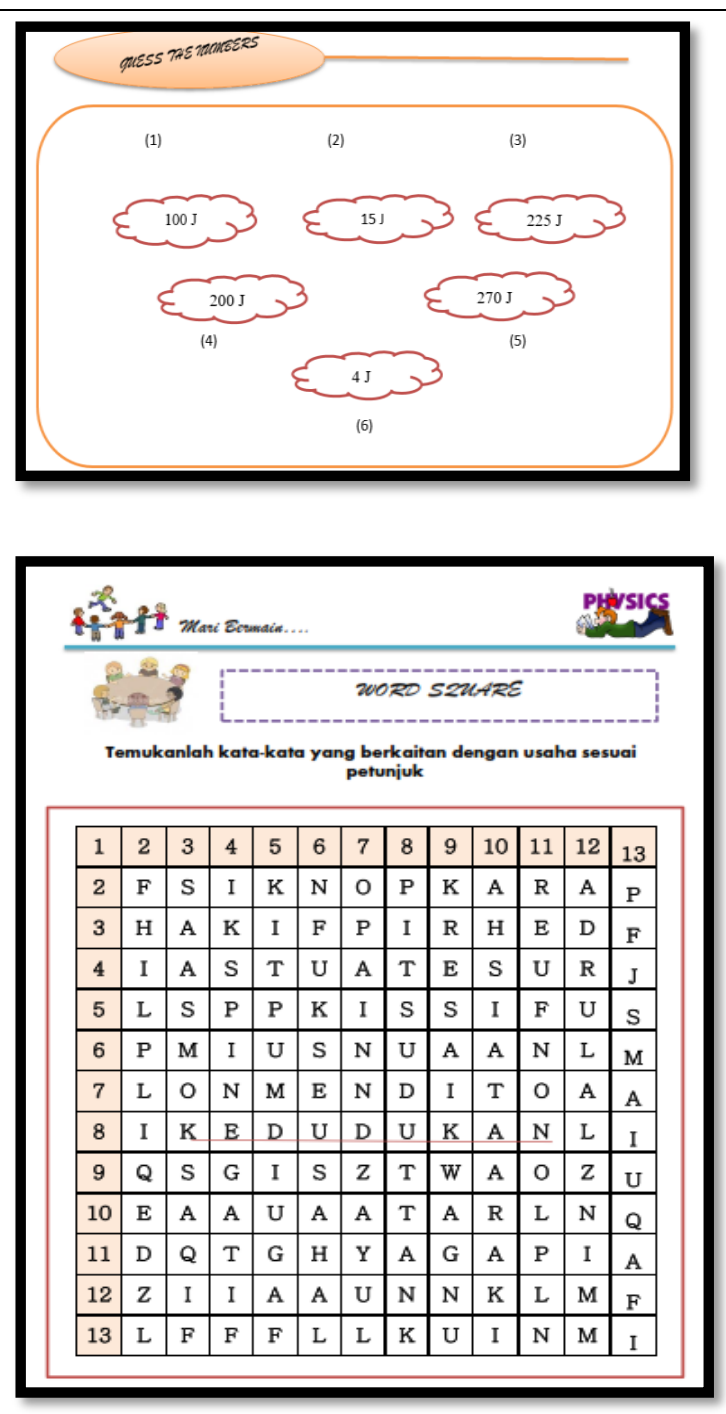

\section{Implementation}

At this stage, validation of student worksheets with Kokami media is based on several aspects. The student worksheets with Kokami media developed were validated by three validators consisted of academics and practitioners. The results of validation can be seen in Table 4.

Table 4. Results of Validation

\begin{tabular}{lll}
\hline Aspects & Average & Category \\
\hline Content & 3.33 & Very good \\
Presentation method & 3.33 & Very good \\
Completeness & 3.67 & Very good \\
Physical & 3.33 & Very good \\
Language & 3.56 & Very good \\
Illustration & 3.17 & Good \\
Validity & 3.40 & Highly valid \\
Reliability & 0.80 & High \\
\hline
\end{tabular}

Based on Table 4, the assessment from aspects of worksheets, students obtained a validity of 3.40 with a highly valid category. The results of the validation of aspects of student worksheets stated that the students' worksheets with Kokami media developed had fulfilled three requirements in the preparation of student worksheets, namely construction, technical, and didactic requirements. So it can be concluded that the student worksheets with Kokami media that have been developed can be implemented as teaching material. This is following the opinion of (Fhadhila et al., 2018) which states that a valid worksheet shows that the worksheet is appropriately implemented as teaching material. 


\section{Evaluation}

This stage aimed to determine the practicality of worksheets using student responses and evaluate the effectiveness of the worksheets. The field testing of the worksheet was given to 36 students of a public junior high school in Barito Kuala regency. The practicality of students' worksheets from learning activities on work and energy materials for 3 meetings can be seen from the students' responses to the questionnaire. The results of the analysis of student responses to the student worksheets used can be seen in Table 5 .

Table 5. Results of Students' Responses toward the Worksheet

\begin{tabular}{lll}
\hline Aspect & Average & Category \\
\hline Ease of use & 3.52 & Very good \\
Benefits & 3.82 & Very good \\
Time & 3.83 & Very good \\
efficiency & & \\
Average & 3.72 & Very good \\
\hline
\end{tabular}

Based on Table 5, it is known that the overall value of the average student response to the student worksheets developed is 3.72 in a very good category. From the results of students' responses obtained, it shows that learning using science students' worksheets with Kokami media developed gave a positive response from students that the science student worksheets with Kokami media used were very good.

This shows that the used science students' worksheets with Kokami media make the learning atmosphere pleasant, encourages students to work together with group members and is active in expressing opinions (Bestari et al., 2014). Students' worksheets developed can be used by students to improve the quality of learning activities and facilitate teachers in teaching. A product is said to be practical if the product is easy to use (Prastowo, 2014).

Based on the explanation above, it can be seen that student worksheets with Kokami media get good responses or responses from students because learning while playing makes students not easily bored in learning and creates a pleasant learning atmosphere. Learning through Kokami media allows students to learn while playing on the material taught so that the lessons given are more memorable (Widodo, 2017). Kokami media is done by discussion, which can stimulate student answers based on previous knowledge obtained from everyday life and then become new knowledge (Mauliana \& Rahmayani, 2017).

Kokami media serves to stimulate interest, attention and provide knowledge to students with interest (Paisah et al., 2013). Kokami media makes student opinions brave and values your opinions with other groups.

The effectiveness of student worksheets can be seen from student learning outcomes measured through the pretest and posttest that were distributed to students before and after the use of natural science students' worksheets with 10-question essay media in the form of Kokami. The results of the NGain test can be seen in Table 6.

Table 6. N-Gain Test Results

\begin{tabular}{llll}
\hline Pretest & Posttest & N-gain & Category \\
\hline 2.45 & 79.10 & 0.79 & High \\
\hline
\end{tabular}

Based on Table 6, the difference in values that are very far between the average value of the pretest and posttest. This shows that student learning outcomes after participating in learning activities using science students' worksheets with overall Kokami media are said to be effective, which means students' abilities increase after participating in learning activities by using science students' worksheets with developed Kokami media. From the results of the overall analysis, most student learning outcomes are in the high category. This proves that learning trials using worksheets of natural science students with Kokami media developed to have an impact on improving student learning outcomes.

Improving student learning outcomes is influenced by the content or components of student worksheets developed. Also, the 
game of Kokami is used when teaching and learning activities get considerable enthusiasm from students and make students feel happy and excited to take part in learning with the game of Kokami in the student worksheet.

The Kokami media developed consists of word square, guess the picture, guess the numbers, crossword puzzle, and guess the word. Kokami media can attract students' interest to be actively involved in the learning process. Kokami media can help students think fast, carefully, dynamically, and creatively, to improve student learning outcomes for the better (Mauliana \& Rahmayani, 2017). Learning media using Kokami (mysterious boxes and cards) can increase motivation (Marga et al., 2018). Learning to use Kokami media through games and discussions between groups results in students' cognitive abilities being more dominant; in addition to that, it will liven up learning activities in the classroom (Istiqomah et al., 2016). This has an impact on better students' learning outcomes (Putri et al., 2017).

\section{CONCLUSION AND SUGGESTION}

The Kokami media in the science worksheet that had been developed was feasible to be used at the junior high school level. This is supported by the product to be in the valid category, has excellent practicality, and has high effectiveness. Based on students' responses, the utilization of Kokami brings a positive effect where science lessons could be both effective and attractive at the same time. The researchers suggest the expansion of topics and schools could enrich this development. The need for science learning to be more aligned with $21^{\text {st }}$-century skills also challenges the researchers to develop an appropriate worksheet.

\section{AUTHOR CONTRIBUTIONS}

MS and MH prepared research design. AS, SH, MW, SM design, conceptualization product, collected and analysed data. NF,
MW and SM writing the result and discussion.

\section{REFERENCES}

Anesia, R., Anggoro, B. S., \& Gunawan, I. (2018). Development of android-based comics media on the subject of straight motion. Indonesian Journal of Science and Mathematics Education, 1(1), 5357.

Ardan, A. S. (2016). The development of biology teaching material based on the local wisdom of timorese to improve students knowledge and attitude of environment in caring the preservation of environment. International Journal of Higher Education, 5(3), 190-200.

Barniol, P., \& Zavala, G. (2016). A tutorial worksheet to help students develop the ability to interpret the dot product as a projection. Eurasia Journal of Mathematics, Science and Technology Education, 12(9), 2387-2398.

Berland, L. K., Schwarz, C. V, Krist, C., Kenyon, L., Lo, A. S., \& Reiser, B. J. (2016). Epistemologies in practice: Making scientific practices meaningful for students. Journal of Research in Science Teaching, 53(7), 1082-1112.

Bestari, D., Yulianti, D., \& Dwijananti, P. (2014). Pembelajaran fisika menggunakan SEA berbantuan games untuk mengembangkan karakter siswa smp. UPEJ Unnes Physics Education Journal, 3(1), 24-29.

Crocco, F., Offenholley, K., \& Hernandez, C. (2016). A proof of concept study of game-based learning in higher education. Simulation \& Gaming, 47(4), 403-422.

Daineko, Y., Dmitriyev, V., \& Ipalakova, M. (2017). Using virtual laboratories in teaching natural sciences: An example of physics courses in university. Computer Applications in Engineering Education, 25(1), 39-47.

Ekantini, A., \& Wilujeng, I. (2018). The development of science student worksheet based on education for 
environmental sustainable development to enhance scientific literacy. Universal Journal of Educational Research, 6(6), 1339-1347.

https://doi.org/10.13189/ujer.2018.060 625

Fhadhila, F., Ertikanto, C., \& Rosidin, U. (2018). Developing student worksheet of temperature and heat based on scientific process skill. Jurnal Ilmiah Pendidikan Fisika Al-BiRuNi, 7(1), 2132.

Forawi, S. A. (2016). Standard-based science education and critical thinking. Thinking Skills and Creativity, 20(2), 52-62.

Haerani, R. P. R. (2016). Penggunaan media pembelajaran video game IPA untuk meningkatkan penguasaan konsep siswa. EDUSAINS, 8(2), 114-121.

Hake, R. R. (1998). Interactive-engagement versus traditional methods: A sixthousand-student survey of mechanics test data for introductory physics courses. American Journal of Physics, 66(1), 64-74.

Hartini, S., Isnanda, M. F., Wati, M., Misbah, M., An'nur, S., \& Mahtari, S. (2018). Developing a physics module based on the local wisdom of Hulu Sungai Tengah regency to train the murakata character. Journal of Physics: Conference Series, 1088(1), 1-6.

Hartini, S., Misbah, M., Dewantara, D., Oktovian, R. A., \& Aisyah, N. (2017). Developing learning media using online prezi into materials about optical equipments. Jurnal Pendidikan IPA Indonesia, 6(2), 313-317.

Hartini, S., Misbah, M., Helda, H., \& Dewantara, D. (2017). The effectiveness of physics learning material based on South Kalimantan local wisdom. AIP Conference Proceedings, 1868(1) 1-7.

Hartini, S., Syahrirani, M., \& Salam, A. (2018). The development of smoky glass box as a physics instructional medium on light subject. Journal of
Physics: Conference Series, 1040(1), 1-6.

Huizinga, T., Handelzalts, A., Nieveen, N., \& Voogt, J. M. (2014). Teacher involvement in curriculum design: Need for support to enhance teachers' design expertise. Journal of Curriculum Studies, 46(1), 33-57. https://doi.org/10.1080/00220272.2013. 834077

Hwang, G. J., Chiu, L. Y., \& Chen, C. H. (2015). A contextual game-based learning approach to improving students' inquiry-based learning performance in social studies courses. Computers \& Education, 81(2), 13-25.

Istiqomah, F., Widiyatmoko, A., \& Wusqo, I. U. (2016). Pengaruh media Kokami terhadap keterampilan berpikir kreatif dan aktivitas belajar tema bahan kimia. Unnes Science Education Journal, 5(2), 1217-1226. https://doi.org/10.15294/usej.v5i2.1191 3

Juneau, J. L. (2017). Implementation of problem-based instruction learning model using media kotak dan kartu misteri to improve student learning outcomes. Jurnal Handayani PGSD FIP UNIMED, 7(2), 137-141.

Labibah, U. N., Wilujeng, I., Sulaiman, S., \& Rahmawati, L. (2019). AndroidBased physics learning media integrated landslide disaster. Jurnal Ilmiah Pendidikan Fisika Al-Biruni, 8(2), 229-236.

Marga, K. M., Isnaini, M., \& Utami, L. S. (2018). Pengaruh media Kokami (kotak dan kartu misterius) terhadap keterampilan berpikir kritis dan motivasi belajar siswa kelas viii smp negeri 19 mataram tahun pelajaran 2017/2018. ORBITA: Jurnal Kajian, Inovasi Dan Aplikasi Pendidikan Fisika, 4(2), 18-25.

Mastuang, M., Misbah, M., Yahya, A., \& Mahtari, S. (2019). Developing the physics module containing Quranic verses to train the local wisdom 
character. Journal of Physics: IOP Conference Series, 1171(1),1-7.

Mauliana, A., \& Rahmayani, R. F. I. (2017). Penerapan model pembelajaran kooperatif tipe teams games tournament (TGT) dengan menggunakan media kokami terhadap hasil belajar siswa pada materi perkembangan model atom kelas $\mathrm{X}$ MIA 4 SMA Negeri 9 Banda Aceh. Jurnal Ilmiah Mahasiswa Pendidikan Kimia, 2(3), 183-192.

Nasution, T. K., \& Sinaga, B. (2017). Development of student worksheet geometry based metacognitive strategy through creative thinking ability. IOSR Journal of Research \& Method in Education (IOSR-JRME, 7(4), 10-18.

Nuraeni, H., Nurhayati, N. D., \& Haryono, H. (2015). Studi komparasi pembelajaran menggunakan kartu destinasi dan kotak kartu misterius (KOKAMI) ditinjau dari kemampuan memori terhadap prestasi belajar siswa pada materi pokok koloid sma muhammadiyah 1 karanganyar tahun pelajaran 2013/2014. Jurnal Pendidikan Kimia, 4(2), 38-46.

Paisah, N., Fatmaryanti, S. D., \& Akhdinirwanto, R. W. (2013). Penerapan media kotak dan kartu misterius (Kokami) untuk peningkatan keterampilan berpikir kritis pada siswa kelas vii smp negeri 25 purworejo. Jurnal Radiasi, 3(1), 28-32.

Prastowo, A. (2014). Panduan kreatif membuat bahan ajar inovatif. Diva Press.

Putri, A. I. K. D., Prihandono, T., \& Putra, P. D. A. (2017). Penerapan model pembelajaran talking stick disertai metode demonstrasi berbantuan media Kokami mata pelajaran ipa di smp. Jurnal Pembelajaran Fisika, 5(4), 321328.

Rachmawati, H. (2019). Implementasi model pembelajaran kooperatif tipe team games tournament (TGT) dengan media pembelajaran kotak dan kartu misteri (Kokami) untuk meningkatkan motivasi belajar dan hasil belajar kelas $\mathrm{x}$ akuntansi di smk muhammadiyah 1 wates tahun ajaran 2017/20. Jurnal Pendidikan Dan Ekonomi, 8(1), 20-26.

Rahmawati, A. M. (2017). Analisis hasil pengembangan media Kokami (kotak dan kartu misterius) untuk meningkatkan keterampilan berpikir kritis, aktivitas belajar dan ketuntasan belajar SMP-SMA. Jurnal Pendidikan Ekonomi (JUPE), 5(3), 1-5.

Sriarunrasmee, J., Suwannatthachote, P., \& Dachakupt, P. (2015). Virtual field trips with inquiry learning and critical thinking process: a learning model to enhance students' science learning outcomes. Procedia-Social and Behavioral Sciences, 197(1), 17211726.

Utami, W. S. (2016). The effectiveness of geography student worksheet to develop learning experiences for high school students. Journal of Education and Learning, 5(3), 315-321.

Wati, M., Hartini, S., Hikmah, N., \& Mahtari, S. (2018). Developing physics learning media using 3D cartoon. Journal of Physics: Conference Series, 997(1), 1-5.

Widodo, P. E. K. (2017). Pengaruh media Kokami terhadap hasil belajar IPS siswa kelas V SDN Sambibulu Sidoarjo. Jurnal Penelitian Pendidikan Guru Sekolah Dasar, 5(3), 1075-1084.

Widoyoko, E. (2014). Evaluasi program pembelajaran. Pustaka Pelajar.

Zainuddin, Z., Hasanah, A. R., Salam, M. A., Misbah, M., \& Mahtari, S. (2019). Developing the interactive multimedia in physics learning. Journal of Physics: Conference Series, 1171(1), 1-5.

Zulyadaini, D. (2017). A Development of students' worksheet based on contextual teaching and learning. IOSR Journal of Mathematics, 13(01), 3038. 